\title{
Creative Industry And Opportunity In Export Market
}

\section{Gusti Ayu Purnamawati ${ }^{*}$, Elly Herliyani², Dewa Ayu Eka Agustini ${ }^{3}$}

1 Faculty of Ekonomi, Universitas Pendidikan Ganesha, Indonesia

${ }^{2,3}$ Faculty of Language and Art, Universitas Pendidikan Ganesha, Indonesia

\section{A R T I C L E I N F O}

Article history:

Received 19 February 2019

Received in revised form 16 March 2019

Accepted 15 April 2019

Available online 26 May 2019

Keywords:

creative industry, exports

market, economic

development

\begin{abstract}
A B S T R A C T
The important role of MSMEs being the largest business sector in its contribution to the national development is also providing the opportunity of considerable job vacancies. Creative Industry can be one of the alternatives in facing the tight competition of the world market, so that the Government have the obligation to find, support the regional potency and create the strategy of creative industry development in order to compete with other regions and other countries. Local Economic Development focuses on endogenous development policy utilizing the potential of local human, institutional and physical resources. Whatever form of policy is taken, LED has one goal, which is increasing the number and variety of job opportunities available to the local population.
\end{abstract}

\footnotetext{
* Corresponding author.

E-mail addresses: ayupurnama07@gmail.com (I Gusti Ayu Purnamawati)
} 


\section{Introduction}

The very same economy of many countries is undergoing significant structural changes as traditional industries replaced by the service sector and innovation, marking the transition to a knowledge economy where a particular role is played by creativity (Čábelková, Strielkowski, \& Mirvald, 2015) (Żelazny \& Pietrucha, 2017). In addition, globalisation 'implies changes, opportunities and threats and not all territories across the world have the same capacity and tools to make the world an even playing field' (Rodriguez-Pose \& Crescenzi, 2008).

Creative industries have been growing and developing in many parts of the world, especially in developed countries. The development of creative industries in certain countries more or is less connected to their own cities. The term creative industries had just been known in Indonesia in the year 2007, when the Ministry of Trade of Indonesia published the Creative Industries Study of Indonesia. Since then, the area of the creative industries has started to be looked at by not only the government, but also by academics and practitioners (Maryunani \& Mirzanti, 2015).

The creative economy is increasingly becoming one of the relevant components of the modern postindustrial economies based on knowledge, due to the perception of its potential to generate income and employment, which is above the average of other sectors, but also because it is a cultural identity forger of some societies through the development process (Kon, 2016). The combination of artistic creativity and local culture, made Bali as one of the provinces which is famous for its craft industry. One of the regions in Bali that can develop craft centers is Gianyar regency. For tourism managers, products that become "market trends" are known by various names, there are various tourist attractions that are highlighted, but the theme are all about uniqueness, nature and conservation. Sustainable Tourism is described as a tourism industry which committed to create a mild impact on the environment, as well as helping the local people to earn money and provide job vacancies. The term that sheltered it is the Sustainable Tourism which subsequently appeared derived names for it (Ernawati, 2010). Creativity is an inexhaustible resource based mainly on the ideas and cultural characteristics rather than on the physical capital (Skavronska, 2017).

Research by (Sarijani, Baedhowi, \& Sawiji, 2015), the result of research shows that creativity and innovation are very much required for product diversification, as they can create new ideas for culinary products. This in turn will increase the sale turnover and income. Product diversification is truly needed if the business condition begins to be threatened by new competitors or to be left by customers. To fix it, a self-exploration attitude is required, that is, the ability to sharpen creativities and implement them in real actions as an embodiment of innovations, so as to have extraordinary contributions to the increase of sale turnovers, customers, and profits. (Knell \& Oakley, 2007) analyzing London's creative economy, identified that the creative industries are a very particular kind of sector - tough to define and to connect. Only the labor and ideas pool sustain the small creative businesses, which in their turn attract the larger ones. Research by (Jiao, Wang, Xiao, Zhou, \& Zeng, 2017), the research analysis shows profit model innovation in animation projects can be divided into Fans mode, Popular mode, Placement mode, and Failure mode, respectively. The collaboration between those various actors who play a role in the creative industry are the intellectual, the business world, and the Government which is as the fundamental prerequisite (Masri, 2010). Research by (Dincer \& Tekin-Koru, 2016), this research provides a firm-level portrait of services exporters along with goods exporters in a developing country. Current findings of firm-level services trade literature suggest that the stylized facts of goods trade apply to services trade as well for a set of developed countries.

Table 1. Export Value Commodity of Handicrafts in Bali Province year 2010-2014

\begin{tabular}{llccccc}
\hline No & $\begin{array}{c}\text { Export } \\
\text { Commodities }\end{array}$ & $\mathbf{2 0 1 0}$ & $\mathbf{2 0 1 1}$ & $\mathbf{2 0 1 2}$ & $\mathbf{2 0 1 3}$ & $\mathbf{2 0 1 4}$ \\
\hline 1 & Woodcraft & 77.805 .653 & 63.341 .444 & 71.493 .260 & 90.618 .137 & 73.243 .287 \\
2 & Crafts Furniture & 30.635 .943 & 30.804 .932 & 34.818 .965 & 28.175 .524 & 34.715 .939 \\
3 & Silver Craft & 26.748 .603 & 27.288 .653 & 21.968 .434 & 23.738 .340 & 22.566 .727 \\
4 & Bamboo Crafts & 9.542 .874 & 10.475 .545 & 12.864 .022 & 9.486 .097 & 18.335 .991 \\
5 & Metal Crafts & 11.914 .775 & 11.652 .365 & 9.741 .524 & 11.228 .568 & 15.211 .828 \\
6 & Other Crafts & 9.656 .360 & 7.683 .409 & 13.743 .145 & 4.185 .235 & 12.798 .507 \\
7 & Rattan Handicraft & 5.354 .023 & 4.175 .064 & 1.586 .506 & 4.024 .449 & 4.427 .508 \\
8 & Terracotta Craft & 7.201 .117 & 4.020 .457 & 3.410 .240 & 2.334 .873 & 2.566 .727 \\
9 & Leather Crafts & 9.901 .719 & 8.484 .569 & 9.705 .384 & 9.236 .328 & 9.541 .913 \\
10 & Padas Stone Craft & 18.506 .462 & 15.359 .503 & 11.484 .690 & 10.265 .244 & 14.772 .477
\end{tabular}




$\begin{array}{llccccc}11 & \text { Craft of Webbing } & 1.535 .987 & 2.448 .140 & 2.085 .820 & 1.062 .490 & 3.643 .201 \\ 12 & \text { Ceramic Crafts } & 1.346 .419 & 1.910 .242 & 1.053 .703 & 1.478 .951 & 1.660 .458 \\ 13 & \text { Shell Crafts } & 2.111 .533 & 1.246 .203 & 945.675 & 1.121 .660 & 2.439 .453 \\ 14 & \text { Painting Crafts } & 1.206 .651 & 1.386 .298 & 1.602 .759 & 2.215 .993 & 2.289 .470 \\ 15 & \text { Musical } & 725.111 & 95.067 & 167.807 & 412.841 & 692.022 \\ & \text { Instruments Craft } & 303.973 & 155.3 & 480.425 & 286.393 & 509.383 \\ 16 & \text { Candle Craft } & 82.164 & 143.677 & 220.887 & 264.182 & 268.788 \\ 17 & \text { Bone Crafts } & & \end{array}$

Source : Department of Industry and Commerce of Bali Province, 2015

The collaboration between 3 (three) actors that play a role in creative industry namely intellectuals, business, and Government is a fundamental prerequisite. Without the collaboration of these three actors, it is feared that the development of creative industry will not be working in accordance with the planned or prepared program, because if they are not working in accordance, there will be an overlap. As is done in Gianyar regency which is a creative industry center of art sculpture that is famous with the nickname of City of Art, precisely in Banjar Pakudui, Desa Kedisan, Tegalalang district, there are human resources that active in art sculpture. It is proven based on the document of Trade and Industry Department of Gianyar Regency, this art of sculpture has the potential to become a commodity that has a significant opportunity in creating the competitiveness of local handicrafts and has penetrated international markets such as the Netherlands, France, Korea and Taiwan. This phenomenon then makes the art sculpture as a superior product of the region and lead the economy in Gianyar regency.

One of the problems faced by UMKM is capital. because the access of MSMEs to the banking sector is still lacking. whereas the capital is necessary for business expansion. Research by (Tian, 2016) find that firms with a larger part of shares owned by the government have lower capacity utilization. Stronger market competition leads to over-investment and therefore lower capacity utilization rate. Faced with more rigorous labor market regulation, firms will substitute capital for the use of labor, resulting in higher capacity utilization rate. The rapid development of creative industry in Gianyar regency has implications for the increasingly fierce competition climate. As a result, for the creative industries that are unable to compete will be displaced from business competition and threatened with bankruptcy. The efforts to make the creative industry to be able to compete, independently and can contribute greatly to the economy of Gianyar Regency is not enough through government policy only. Therefore it is necessary to strive for strategic steps in developing creative industries in Gianyar Regency. (Morgan, 2009), and also in line with (Vargas-Hernández \& Noruzi, 2010), state that the long-term government coaching and empowerment can play a role in improving the competitiveness of MSMEs in a sustainable way. Research by (Hidayat \& Asmara, 2017), state that economy creative is one of new economy sources which is promoted by Government of Indonesia. Many creative sectors are pushed to complete national economy in Indonesia. The result is that creative industry and innovation are mutual relation each other in conceptual level. Practically, both are aimed to support national economy growth in Indonesia. Research by (Daubaraitė \& Startienè, 2015) to define impact of creative industries (CI) on national economy in regard to sub-sectors. The findings of this research provide the basis for targeted funding in order to foster and develop CI impact on national economy.

In the effort to develop creative industry in Gianyar regency, there are some problems faced in the process, such as: (1) the absence of detailed information about the number of business units, the number of workers and the performance of creative industries in Gianyar Regency. The perceived performances are export capability, competitiveness, value added contribution and job vacancies, labor productivity, and capital productivity, (2) the absence of common pattern and reference in the preparation of programs for development interests and the division of roles from various related institutions involved in the development of Small and Medium Enterprises (SMEs) in Gianyar Regency. The implication of the second problem is the absence of a conceptual, directional and effective guidance system that guides the building apparatus in developing creative industries in Gianyar Regency.

To overcome the problems in developing creative industries in Gianyar Regency, there are many factors influenced. In general, these factors can be classified into 2 (two) groups, namely: external factors and internal factors. External factors are factors from the outside of the industrial environment, but affect the decision-making, such as government policy, legal and political forces, technology, competitors, and market desires. External factors above need to be studied in order to know the opportunities and challenges in the development of the industry. (Florida, 2003) says that the human capital theory establishes creativity people, it is also the driving force in regional economic growth. From that perspective, economic growth will occur in place that have highly educated people. Again he reinforces 
that new geography and creativity shift to powerful migratory trends and emerging new economic geography.

The purpose of this study was to provide design strategies for small and medium business development that was expected to be used as an input for the development of creative artistic industry of Gianyar sculpture. Based on the background above, there were several problems studied in this study, namely: (1) What are the factors that support the community in developing the creative industry?; (2) How is the tourists' potential to the art sculpture marketed in the tourism area?; (3) What is the effort and policy of the local government in providing job vacancies?; (4) What is the design of the management system of export market in creative industry?

\section{Methods}

This study is descriptive-quantitative research. Subjects determination in this study used the Purposive Sampling technique. This study used survey method, that is a study which takes sample from population and uses questionnaire as data collection tool and the approach used was by using quantitative approach. In addition, this study also used a qualitative approach to obtain as much information as possible through observation and in-depth interviews. In-depth interviews are the process of obtaining information for the purpose of study by means of question and answer while meeting face-to-face between the interviewer and the interviewee, with or without using interview guides, and focus groups discussion (Bungin, 2010).

The subjects in this study were the Department of Trade and Industry in Gianyar regency, sculpture artisans in Gianyar and consumers as the users of the typical Gianyar art sculpture. While the object of this study was the income of typical Gianyar art sculpture creative industry. To know the factors and the influence of these factors on the centers development, multivariate statistical analysis was used, i.e. factor analysis. This analysis was used with the help of SPSS software.

The validity and reliability test used in this study was to test the instrument used. Test validity used Product moment correlation, if the correlation value is more than 0.3 then the instrument is valid. While the reliability test used internal consistency method by looking at the value of Alpha Crombach. When the value of Alpha Crombach is more than 0.7 then the research instrument is reliable (Ghozali, 2011).

This study used factor analysis which then yields factor rotation value and variant value of each variable that can be used for weighting in further strategy analysis. In the SWOT analysis the strengths, weaknesses, opportunities, and threats to the development of Gianyar art sculpture creative industry were examined.

\section{Result and Discussion}

The results of the preliminary factor analysis showed that there were 24 tested variables, which can be used for further analysis, namely: production area, production building, distance to market, availability of infrastructure, quantity of raw materials, skill, amount of labors, marketing, organization structure, research and development, legal entities, capital, loans, capital institutions, subsidies, spatial concentration, interaction, combinations of competencies, joint institutions, specialization, competitiveness, and identity.

The variables studied were 23 variables, which the validity and reliability had been tested in the previous stage. That variable was tested using factor analysis. The 23 tested variables were then tested using KMO and Bartlet test values, and the MSA (Measures of sampling adequacy). MSA value must be more than 0.5. Based on the statistical tables obtained the number of KMO and Bartlet test was 0.731 with 0.000 at the significant level. Therefore, variables and samples can be analyzed further. The MSA figures in the anti-matrix table contained in the anti-correlation image shows the value of production land $\left(\mathrm{X}_{1.1}\right)$ is 0.633 , the production building $\left(\mathrm{X}_{1.2}\right)$ is 0.488 , the distance to the market $\left(\mathrm{X}_{1.3}\right)$ is 0.676 , the availability of infrastructure $\left.\mathrm{X}_{1.4}\right)$ is 0.978 , the amount of raw material $\left(\mathrm{X}_{1.5}\right)$ is 0.982 , the skill $\left(\mathrm{X}_{1.6}\right)$ is 0.944 , the amount of labor $\left(\mathrm{X}_{1.7}\right)$ is 0.982 marketing $\left(\mathrm{X}_{1.8}\right)$ is 0.951 , the capital $\left(\mathrm{X}_{1.9}\right)$ is 0.982 , the spatial concentration $\left(\mathrm{X}_{1.10}\right)$ is 0.791 , and the interaction $\left(X_{1.11}\right)$ is 0.635 . The organizational structure $\left(X_{2.1}\right)$ is 0.937 , the research and development $\left(\mathrm{X}_{2.2}\right)$ is 0.961 , the legal entity $\left(\mathrm{X}_{2.3}\right)$ is 0.720 , and the combination of competence $\left(\mathrm{X}_{2.4}\right)$ is 0.776 , the joint institution $\left(\mathrm{X}_{3.1}\right)$ is 0.791 and specialization $\left(\mathrm{X}_{3.2}\right)$ is 0.982 . $\left(\mathrm{X}_{4.1}\right)$ is 0.967 , labor $\left(\mathrm{X}_{5.1}\right)$ is 0.810 and competitiveness $\left(\mathrm{X}_{5.2}\right)$ is 0.967 , subsidy $\left(\mathrm{X}_{6.1}\right)$ is 0.847 , and the Identity $\left(\mathrm{X}_{6.2}\right)$ is 0.680 . Of the 23 variables, the smallest MSA is the production building $\left(\mathrm{X}_{1.2}\right)$ with a value of 0.488 . Therefore the production building $\left(\mathrm{X}_{1.2}\right)$ is removed from the factor because it has the smallest MSA value. After the production building variable $\left(\mathrm{X}_{1.2}\right)$ is excluded from the factor. The total variance explained table describes the number of factors formed that can be seen on its eigenvalue that is more than 1 . 
Based on the result of factor analysis, there are six groups of factors that influenced the development of the center. These factors are grouped based on the size of the variance (eigenvalue) owned by each component. The component matrix of the rotation process result shows the distribution of variables more clear and real. It appears that the small loading factor is minimized and the larger loading factor is enlarged. The six groups of factors are:

Factor 1, named "basic resource factor $\left(\mathrm{X}_{1}\right)$ " which consisted of production land $\left(\mathrm{X}_{1.1}\right)$, production building $\left(\mathrm{X}_{1.2}\right)$, distance to market $\left(\mathrm{X}_{1.3}\right)$, availability of infrastructure $\left(\mathrm{X}_{1.4}\right),\left(\mathrm{X}_{1.7}\right)$, marketing $\left(\mathrm{X}_{1.8}\right)$, capital $\left(\mathrm{X}_{1.9}\right)$, spatial concentration $\left(\mathrm{X}_{1.10}\right)$, and interactions $\left.\left(\mathrm{X}_{1.5}\right), \mathrm{X}_{1.6}, \mathrm{X}_{1.11}\right)$.

Factor 2, named "supporting institutional factor $\left(\mathrm{X}_{2}\right)$ " which consisted of organizational structure $\left(\mathrm{X}_{2.1}\right)$, research and development $\left(\mathrm{X}_{2.2}\right)$, legal entity $\left(\mathrm{X}_{2.3}\right)$, and combination of competence $(\mathrm{X} 2.4)$.

Factor 3, named "group factor for specialization $\left(\mathrm{X}_{3}\right)$ " which consisted of joint institutions $\left(\mathrm{X}_{3.1}\right)$ and specialization $\left(\mathrm{X}_{3.2}\right)$.

Factor 4, named "investment factor $\left(\mathrm{X}_{4}\right)$ " which consisted of loans $\left(\mathrm{X}_{4.1}\right)$, and capital institution $\left(\mathrm{X}_{4.2}\right)$.

Factor 5, named "labor and competitiveness factor $\left(\mathrm{X}_{5}\right)$ " which consisted of labor $\left(\mathrm{X}_{5.1}\right)$ and competitiveness $\left(\mathrm{X}_{5.2}\right)$.

Factor 6, named "subsidy factor $\left(\mathrm{X}_{6}\right)$ " which consisted of subsidy $\left(\mathrm{X}_{6.1}\right)$, and identity $\left(\mathrm{X}_{6.2}\right)$.

Table 2. Component Transformation Matrix

\begin{tabular}{ccccccll}
\hline Component & & \multicolumn{1}{c}{1} & \multicolumn{1}{c}{2} & \multicolumn{1}{c}{3} & \multicolumn{1}{c}{4} & \multicolumn{1}{c}{5} & \multicolumn{1}{c}{6} \\
\hline \multirow{3}{*}{ Dimension } & 1 & 0.524 & 0.703 & 0.339 & 0.776 & 0.751 & 0.766 \\
& 2 & -0.642 & -0.624 & 0.641 & 0.973 & -0.956 & 0.952 \\
& 3 & 0.801 & 0.621 & 0.596 & 0.973 & 0.971 & -0.957 \\
& 4 & -0.414 & 0.351 & 0.462 & 0.638 & 0.640 & 0.609 \\
& 5 & -0.443 & 0.167 & -0.497 & -0.494 & -0.563 & -0.478 \\
& 6 & 0.626 & 0.518 & -0.555 & 0.854 & 0.845 & 0.825 \\
\hline
\end{tabular}

Extraction Method: Principal Component Analysis. Rotation Method: Varimax with Kaiser Normalization. Source: statistical results

From the table above, it can be explained that the diagonal factor (component) are $0.524 ;-0.624$; $0.596 ; 0.638 ;-0.563 ; 0.825$. The minus number indicates the direction of the correlation. A number above 0.5 indicates there are other components that have a high correlation value.

In its development, the handicraft industry involves various aspects including raw materials, capital/ investment, machinery/ production equipment, manpower, management, promotion and supply. (Travkina \& Tvaronavièiene, 2011), the relationships between export competitiveness and separate productivity factors are complex. In the research it is assumed, that export competitiveness is derivative of main factors' productivities, therefore properly presented and juxtaposed data on labour, capital and energy productivity/intensity would provide with new insights about character of relations between export competitiveness and main production factors productivities. The development of handicraft industry in Gianyar Regency has experienced ups and downs because it is influenced by internal factors such as capitals, labors and materials or materials used for wood carving production and external factors such as technology and communication, promotion and security and protection. This can be seen from the fluctuations in the number of large and small industrial companies as well as the number of workers who can be employed. According to (Squazzoni, 2009) this research deals with the pivotal role played by community development corporations (CDCs) in local economic initiatives from the bottom-up. This research has reported two case studies of local economic development initiatives in North America that are centered on two CDCs. The positive effects and critical points of CDCs have been addressed. The comparison of large and small industries in the use of labor in 2016 can be presented in table 3.

Table 3. Number of Large and Medium Manufacturing Enterprises, Manpower, and Manpower Expenditure According to Gianyar Industrial Functional Groups in 2016

\begin{tabular}{ccc}
\hline Classification of Processing Industry & Number of Companies & Amount of Labor \\
\hline (1) & $\mathbf{( 2 )}$ & (3) \\
\hline Food & 2 & 131 \\
Textile & 12 & 529 \\
Wood, Wooden Goods, and Cork & 28 & 1189
\end{tabular}


Metal, Non Machinery, and Equipment Goods Other Processing Total
12

20

74

778

885

3710

Source: Central Bureau of Statistics of Bali Province, 2014.

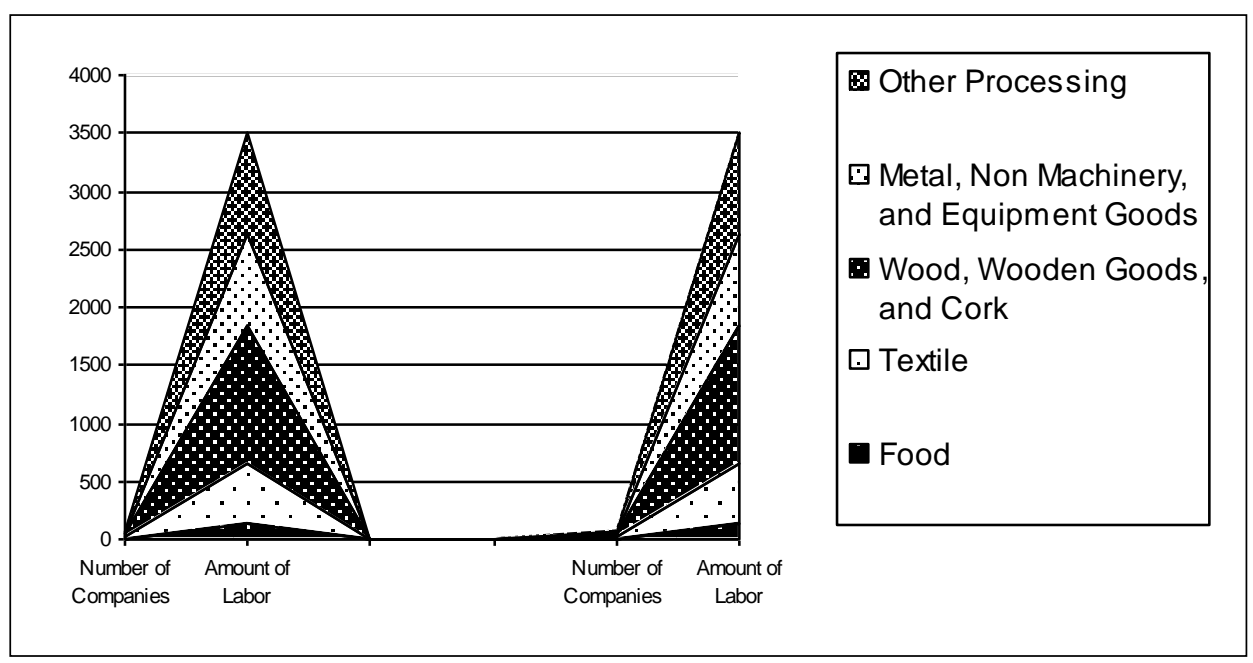

Figure 1. Gianyar Industrial Functional Groups

Table 3 and Figure 1, shows that the wood processing industry, timber and cork goods show the highest amount for the number of companies and employment in the year 2016.

Based on the data described in table 1, shows that the wood industry is more developed in Gianyar regency. This is not apart from the potential of labor that support the smoothness of the woodcarving industry. Driven by factors of work experience and technological developments affect the productivity of labor that will increase the income. According to (Zahonogo, 2016) this study investigates how trade openness affects economic growth in developing countries, with a focus on sub-Saharan Africa (SSA). The research findings are promising and support the view that the relation between trade openness and economic growth is not linear for SSA. Accordingly, SSA countries must have more effective trade openness, particularly by productively controlling import levels, in order to boost their economic growth through international trade. Work experience is a skill possessed by the labors in carrying out operations that support the business activities of the industry. As well as the technological developments as the inspiration in improving creativity in creating the diversity of handicrafts. Based on the factors above, which can be assessed to support the existence of wood carving artisans to the productivity of artisans to support the income of woodcarving artisans in Gianyar regency.

Local Economic Development (LED) concept is a fundamental change in the factors and activities associated with economic development. LED is essentially a partnership process between the local governments and stakeholders including the private sector in managing natural resources and human and institutional resources both through a partnership pattern with the aim to encourage the growth of regional economic activities and create new jobs. Research by (Mensah, Domfeh, Ahenkan, \& Bawole, 2013), local economic development involves identifying and using primarily local resources, ideas and skills to stimulate economic growth and development, with the aim of creating employment opportunities, reducing poverty, and redistributing resources and opportunities to the benefit of local residents. Growth and development cannot take place in an institutional and legal vacuum. Local development and growth require an institutional and legal framework that allows development to take place in an orderly manner and in which agents know that the decisions they take and the contracts they make will be protected by law, and enforced. The findings show that over the years several institutions and policies have been put in place to help improve development at the local level. It is therefore important to build the local capacities and strengthen these institutions to be able to exploit local resources and to stimulate economic development at the local level. (Nijaki \& Worrel, 2012), Green local economic development can be achieved by melding together procurement programs previously singularly focused on either economic development aims, or environmental preservation. It is found that procurement can be used as a viable tool in fostering both economic and environmental goals, and as a key policy and planning tool for sub-national governments in the pursuit of a green economy. (Heideman, 2011), the pilot project is 
attempting to show that municipal LED staff can play the role of facilitator for initiating the enterpriseidentification process and further mobilise state enterprise support agencies around the locus of LED, without crossing the line between facilitation and implementation of 'projects'.

According to (Mokoena, 2017), the outcomes point to the fact that LED can only contribute positively towards the growth of the economy of the country if the environment, in which SMMEs operate, is favourable for the SMMEs to prosper. LED is seen as a contemporary approach in the local government development process. shows that the volume and range of African LED scholarship has progressed considerably, especially over the past decade. (Rogerson \& Rogerson, 2010), LED given the particular significance of tourism in African economies, additional work is warranted to expand the potential for local linkages concerning employment, sourcing and procurement, SMME development, and outsourcing. Further exploring this nexus of LED and tourism is a vital African challenge for scholars of urban as well as rural tourism.

One of the regions that have applied the concept of local economic development in developing its area is Gianyar Regency. The strategy of LED application in Gianyar Regency through partnership forum has been proven in increasing the local capacity both ability of stakeholders cooperation and optimization of local natural resources. However, it does not mean the process and practice of applying the concept of LED in Gianyar regency works optimally. The weakness of LED process in Gianyar Regency needs to be reviewed further. This is necessary, especially as materials for correction, evaluation, and anticipation in the planning process of LED application in other areas. Thus, the study of the LED concept can further illustrate a more developed LED framework in the pursuit of sustainable development.

The strategy applied in local economic development in Gianyar Regency was implemented through Partnership for Local Economic Development (KPEL) approach. KPEL is one of the approaches to encourage economic activity, public-private partnerships and to focus on the development of economic cluster activities, thus establishing linkages between economic actors in a region and the market. The KPEL program in Gianyar regency began in 2016 using the three core strategies: to safeguard interests and involvement, stakeholders joined a District Partnership Forum for Local Economic Development (FKKPEL). FKKPEL prepares forums for dialogue, planning, strategy development and decision-making related to the development of clusters of woodcarving artwork and the local economy. The members of FKKPEL are including the local government (Bappeda, Gianyar Regency, Department of Industry and Commerce, Culture and Tourism Agency), artist groups, cooperative artist. The role of FKKPEL in the local economic development of Gianyar Regency is to encourage the establishment of the organization or collective basis, improve the skills and capacity of handicraft products and prepare a container for producers to engage in planning and policy making, in order to support the capacity of tourist visits to buy art sculpture products produced for souvenirs and art collections purpose. According to (Pike, Marlow, McCarthy, O'Brien, \& Tomaney, 2015), the reasearch examines the roles of local institutions in economic development at the local level. It demonstrates: how local economic development institutions work within multi-agent and multi-scalar institutional settings; the ways institutional genealogy shapes processes of layering and recombining as well as dismantling and improvising in episodes of institutional change and the analytical themes able to explore the roles and functions of institutions in local economic development.

Local community responses are also characterized by the rapid development of handicraft industries such as: silver, gold, weaving and other tourism services. This local community response, accompanied by the growing awareness of Balinese society towards the economic opportunities and benefits of tourism. The involvement of local communities, both individually and as a group grows very fast, such as handicrafts, art-shops, arts for tourists, rafting, diving, restaurant, etc. The growth of the tourism economy sector is growing faster, involving the wider community and more competitive. The involvement of villages in Bali in tourism sector can be grouped into three areas, namely: (1) the villages where tourists live provide accommodation facilities for tourists, such as: hotels and home stays, like in Kuta, Sanur and Ubud, (2) villages visited by tourists include villages with tourism objects and attractions, such as: historical and archeological objects, ancient villages, dances and museums, like in Batubulan (dance), Celuk (silver craft), Mas (wood carving), Tenganan (ancient village), etc., (3) the villages with various potentials that can support tourism development, such as: Guwang Village with the potential of wood carving, Sedang Village with the potential of handicraft art and dance.

This interaction pattern has a profound impact beyond the limits of physical and economic life, to social life (community and kinship), personality (knowledge and attitude), and cultural boundaries (value systems and symbols), but also extends to Psycho-socio-culture. This can only happen because of the personality of the Balinese people is open-minded, dynamic and flexible.

The role of small industries is proven to assist the government in the poverty marginalizing programs and reduce unemployment in equity and job vacancies for the community. The importance of 
small industries' role that can be seen from various things and from the use of local production factors as the main inputs in production activities, the production of goods or services will be used to meet local needs for local consumers and producers in the economic sector. The development of the industrial sector greatly contributed to the growth rate of the industry, increased employment opportunities and increased public income and demand. The industrial sector can also improve and utilize the existing resources optimally, and able to compete with the broader level (Widyana, 2013).

Local Economic Development focuses on "endogenous development" policy utilizing the potential of local human, institutional and physical resources. Whatever form of policy is taken, LED has one goal, which is increasing the number and variety of job opportunities available to the local population. To reach that goal, local government and community groups are required to take the initiative and should not just be a passive role. Every policy and decision of the public and business sectors, as well as the decisions and actions of the people, must be pro-LED, or synchronous and support the regional economic development policies that have been mutually agreed upon. In other words, local economic development activities, like other public activities, are not independent or interrelated with other public aspects. Handicraft industry is an industry that mostly done by Micro Small and Medium Enterprises (MSMEs), this is due to the market potential of the industry.

Research by (Abbott \& Tarp, 2012), showed that Vietnam has been among the most successful East Asian economies, especially in weathering the external shocks of recent globalization crises. Examination of economic performance and policy responses shows rising dependence on foreign finance around each crisis, and actions by the government to counteract that dependence and bolster the domestic economy while continuing to restructure the economy toward greater emphasis on the private sector. Growth, employment and poverty alleviation have been maintained at the expense of renewed inflation, larger budget deficits, and currency depreciation. The "stop-go" nature of present macroeconomic policy is the consequence of balancing growth versus inflation, responding to severe external shocks and holding to a growth objective in the face of substantial internal and external criticism.

a. Development Strategy

To generate the development strategy, SWOT strategy alternative analysis was used. In an alternative analysis of SWOT strategies, the potentials and problems obtained in the previous analysis were classified into components of strengths (S), weakness (W), opportunities (O), and threat (T), then alternative strategies were obtained by integrating internal components ( $\mathrm{S}$ and $\mathrm{W}$ ) and external components (W and T), so as to derive a combination of SW, SO, WT, and WO strategies.

b. Development Concepts

The concept of development of Agro-industry Center of Gianyar Regency art sculpture was basically an explanation of avoiding threats by utilizing its own advantages, development concept.

c. Forms of Government Policy in Preserving the Existence of Export Markets

The realization of policies is influenced by the most important part of government instruments. In this case, is covered by the legal entity and the technical implementation of the policy itself. As stated above, the most important thing of the realization of the policy is because there are internal and external factors. In the internal factors we know that regulate all aspects of the regulation is the rule of law from the center to the region. While, external factors are those who dabbled directly with the conditions in the field, for examples are market participants, market leaders and related offices.

d. Empowerment of Market Participants

In lection, empowerment means reinforcing. Technically, the term empowerment can be equated or at least synonymous with the term development. Empowering the community is an effort to improve the dignity of the layers of society that are now unable to escape the poverty. Furthermore, the starting point of empowerment is the recognition that every human being or every society has potential that can be developed. Empowerment is to build that power by encouraging, motivating, and awakening awareness of the potential that it has and the effort to develop it. Followed by strengthening the potential or power that the community have. Empowerment is essentially a concept with power as the focus. Empowerment is substantially a breaking process of the relationship between the object and the subject. Prioritize selfemployment of the empowered person to achieve his or her empowerment. First, empowerment by creating an atmosphere or a developing climate. Second, empowerment to strengthen the economic potential or power owned by the community. Third, empowerment through the development of the people's economy, by protecting and preventing unfair competition, and creating togetherness and partnership between the already developed and the underdeveloped partnerships. As mentioned above, one of the empowerment elements is creating the market participants which create of a conducive atmosphere and balance in economic. Viewed from the climate of community development, it is the creation of mainstream economic community that is considered important and effective in meeting people's needs. 
e. Cooperatives and Revolving Funds

Cooperative is basically a value system. The values assumed by the cooperative, universally, can be recognized by what is called the basic or cooperative principle. As stated in Article 5 of the Cooperative Act No. 25 In 1992, the principle of cooperative includes five things as follows: 1). Membership is open and voluntary, 2). Management is managed democratically, 3). The distribution of the remaining results of operations is done fairly in proportion to the business services of each member, 4). Provision of limited remuneration of capital, and 5). Independence. Nevertheless, in accordance with the five principles it is noted that cooperative artisan in Gianyar regency in 2011 were already had legal status. From the data, it has been able to contribute quite well in Gianyar society in general. Because, cooperatives are economic products that are structured to create a populist economic system. With so many cooperatives and it is facilitated in the form of services for the community, undoubtedly become a local economic system which is quite effective. Moreover, some cooperatives artisans in Gianyar Regency have been able to enter the leading cooperative at the Provincial level. So far, the cooperative has been able to become a part of Gianyar society. Moreover, the cooperative has been shooting into the village which is usually called Village Cooperative Unit (Koperasi Unit Desa). In this case, VCU has entered the traditional market plot which became the most important part in the provision of loan funds for market participants who lack in capital. Aside from being a value system, cooperatives can also be utilized in terms of the reduction of rampant lenders in the traditional market. Furthermore, in sustaining the economic development in traditional markets, the government in Gianyar regency provides rotating funds for the community. This is in line with the government's preferred policy program that is given to the lead merchants and artisans who are subjected to the operation of loan lenders. In practice, people may apply for a maximum loan of Rp. 1,000,000, - with the installment system for 100 times with only $2 \%$ of interest.

\section{Conclusion}

The factors of community's potential which support the developing creative industry such as: basic resources, supporting institutions, group factor for specialist, investment factor, labor, competitiveness and subsidies.

The tourists' potential to the art sculpture that is marketed through traditional markets in the area of tourism is very dependent on the tourists visits who are considered to be able to boost the number of handicraft production that is usually bought for souvenirs. The impact of the development of art sculpture industry, can increase the production capacity for the artisan, provide job vacancies, including expanding the market scope of typical Gianyar art sculpture in creative industry product.

It is hoped that the government in Gianyar regency especially the Industry and Trade Office to proactively provide the socialization continuously to give understanding of the importance of coordination among MSMEs artisans in increasing production capacity, management, and marketing. It is also hoped that the cooperative artisans are able to cultivate intensive coordination to work together to develop a proactive attitude to exhibition, training, capital improvement. Increase the alignment of knowledge and experience which gained from intelligence, skills, social attitudes, and the attitude relegi aspects which are as the background of the development of craft products preservation of local village handicraft products.

\section{Reference}

Abbott, P., \& Tarp, F. (2012). Globalization Crises, Trade And Development In Vietnam. Journal of International Commerce, Economics and Policy, 3(1), 1-23.

Bungin, B. (2010). Metodologi Penelitian Kuantitatif (Edisi Kedu). Jakarta: Prenada Media Group.

Čábelková, I., Strielkowski, W., \& Mirvald, M. (2015). Business influence on the mass media: a case study of 21 countries. Transformation in Business \& Economics, 14(1), 65-75.

Daubaraitè, U., \& Startienè, G. (2015). Creative Industries Impact on National Economy in Regard to Subsectors. In Procedia - Social and Behavioral Sciences (pp. 129-134). Elsevier.

Dincer, N. N., \& Tekin-Koru, A. (2016). A league of their own: services exporters - a developing country perspective. The Journal of International Trade \& Economic Development, 25(5), 615-635.

Ernawati, N. M. (2010). Tingkat Kesiapan Desa Tihingan-Klungkung, Bali Sebagai Tempat Wisata Berbasis 
Masyarakat. Analisis Pariwisata, 10(1), 1-8.

Florida, R. (2003). Cities and Creative Class. City and Community. American Sociological Association, 2(1), 1-19.

Ghozali, I. (2011). Aplikasi Analisis Multivariate Dengan Program SPSS (5th ed.). Semarang: BP Universitas Diponegoro.

Heideman, L. (2011). Municipal Local Economic Development and the Multiplier effect: Piloting a Community Enterprise Identification Method in South Africa and Namibia. Commonwealth Journal of Local Governance, (8 \& 9), 85-111.

Hidayat, A. R. T., \& Asmara, A. Y. (2017). Creative industry in supporting economy growth in Indonesia: Perspective of regional innovation system. In IOP Conference Series: Earth and Environmental Science (pp. 1-10). IOP Publishing.

Jiao, H., Wang, Y., Xiao, H., Zhou, J., \& Zeng, W. (2017). Promoting Profit Model Innovation in Animation Project in Northeast Asia: Case Study on Chinese Cultural and Creative Industry. Sustainability, 9(2361), 1-17.

Knell, J., \& Oakley, K. (2007). London's Creative Economy: An Accidental Success? Provocation Series, 3(3), 5.

Kon, A. (2016). on the creative economy chain in Brazil: potential and challenges. Brazilian Journal of Political Economy, 36(1), 168-189.

Maryunani, S. R., \& Mirzanti, I. R. (2015). The Development of Entrepreneurship in Creative Industries with Reference to Bandung as a Creative City. In Procedia - Social and Behavioral Sciences (pp. 387394). Elsevier.

Masri, A. (2010). Pendekatan Desain Bagi Industri Kerajinan Kreatif Sebuah Usulan Bagi Program Implementasi Ekonomi Kreatif di Sektor Industri Kerajinan Indonesia. In "Strategi UMKM \& IKM Menghadapi "Asean China Free Trade Area" (ACFTA) dan Inplementasinya dalam upaya memperkuat dan mengembangkan kemampuan diri. Universitas Pakuan Bogor.

Mensah, J. K., Domfeh, K. A., Ahenkan, A., \& Bawole, J. N. (2013). Policy and institutional perspectives on local economic development in Africa: The Ghanaian perspective. Journal of African Studies and Development, 5(7), 163-170.

Mokoena, S. K. (2017). The role of Local Economic Development (LED) : some empirical findings on the Small, Medium and Micro Enterprises (SMMEs). Journal of Public Administration, 52(2), 466-479.

Morgan, J. Q. (2009). The Role of Local Government in Economic Development Survey Findings from North Carolina.

Nijaki, L. K., \& Worrel, G. (2012). Procurement for sustainable local economic development. International Journal of Public Sector Management, 25(2), 133-153.

Pike, A., Marlow, D., McCarthy, A., O’Brien, P., \& Tomaney, J. (2015). Local institutions and local economic development: the Local Enterprise Partnerships in England. Cambridge Journal of Regions, Economy and Society, 8(2), 185-204.

Rodriguez-Pose, A., \& Crescenzi, R. (2008). Mountains in a flat world: Why proximity still matters for the location of economic activity. Cambridge Journal of Regions, Economy and Society, 1, 371-88.

Rogerson, C. M., \& Rogerson, J. M. (2010). Local economic development in Africa: Global context and research directions. Development Southern Africa, 27(4), 465-480.

Sarijani, E., Baedhowi, \& Sawiji, H. (2015). Peran Kreativitas Dan Inovasi Pelaku Usaha Dalam Diversifikasi 
Produk Kuliner Pada Kedai Steak \& Chicken Di Kab. Magetan Tahun 2014 (Implementasi Pendidikan Kewirausahaan).

Skavronska, I. V. (2017). Creative Industries In Ukraine: Analysis And Prospects Of The Development. Economics and Sociology, 10(2), 87-106.

Squazzoni, F. (2009). Local economic development initiatives from the bottom-up: the role of community development corporations. Community Development Journal, 44(4), 500-514.

Tian, X.-L. (2016). Participation in export and Chinese firms' capacity utilization. The Journal of International Trade \& Economic Development, 25(5), 757-784.

Travkina, I., \& Tvaronavièiene, M. (2011). Export Competitiveness and Domestic Productivity Facets: Case of Lithuania. JJournal of Business Economics and Management, 12(1), 49-68.

Vargas-Hernández, J. G., \& Noruzi, M. R. (2010). Study on Entrepreneurship and Role of Government in Enhancing Entrepreneurship by Establishing Small and Medium Enterprises, SMEs and Start-Ups.

Zahonogo, P. (2016). Trade and economic growth in developing countries: Evidence from sub-Saharan Africa. Journal of African Trade, 3(1-2), 41-56.

Żelazny, R., \& Pietrucha, J. (2017). Measuring innovation and institution: the creative economy index. Equilibrium. Quarterly Journal Of Economics And Economic Policy, 12(1), 43-62. 